\title{
Proteus mirabilis strains of diverse type have IgA protease activity
}

\author{
B. W. SENIOR, MERETE ALBRECHTSEN* and M. A. KERR*
}

Department of Medical Microbiology and "Department of Pathology, Dundee University Medical School, Ninewells Hospital, Dundee DD1 9SY

\begin{abstract}
Summary. A strain of Proteus mirabilis associated with chronic urinary tract infection was found to produce an EDTA-sensitive IgA protease that cleaved the IgA heavy chain into two fragments at sites different from those attacked by other microbial IgA1 proteases. Another $14 \mathrm{P}$. mirabilis strains of diverse type and from various clinical conditions also produced a similar $\operatorname{IgA}$ protease. This enzyme may be a virulence determinant of $\boldsymbol{P}$. mirabilis.
\end{abstract}

\section{Introduction}

Although infections of the urinary tract with Proteus mirabilis occur less frequently than those with Escherichia coli except in young boys (Bergström, 1972; Hallett et al., 1976; Khan et al., 1978) and the elderly (Walkey et al., 1967; Senior, 1979), the consequences may be more serious. The predilection of $P$. mirabilis is for the upper urinary tract (Fairley et al., 1971; Svandborg Edén et al., 1980) where damage to the renal tubular epithelium (Braude et al., 1960) and stone formation (Griffith et al., 1973) may take place.

The virulence of $P$. mirabilis for the urinary tract may arise through the interplay of several factors including rapid growth in urine and the formation of potent urease isoenzymes which are important in human and experimental urinary tract infections (MacLaren, 1968 and 1969; Musher et al., 1975; Senior et al., 1980; Senior, 1983a). Motility also appears to be important in establishing ascending pyelonephritis (Pazin and Braude, 1974). P. mirabilis cells, unlike those of $E$. coli, have the ability to directly invade mammalian cells (Braude and Siemienski, 1960; Peerbooms et al., 1984) possibly through the activity of a cell-bound haemolysin (Peerbooms et al., 1983). The presence of certain fimbriae (Silverblatt, 1974; Silverblatt and Ofek, 1978), proticines and proticine receptors (Senior, 1979) may also be associated with $P$. mirabilis virulence but the relative importance of these factors is still unclear (Adegbola et al., 1983; Senior, 1983b).

In this study the ability of $P$. mirabilis strains associated with urinary tract infections to produce

Received 22 Sept. 1986; revised version accepted 6 Jan. 1987. a new type of $\operatorname{IgA}$ protease was demonstrated. Production of this enzyme in vivo may enable $P$. mirabilis to overcome the antibody defence of the urinary tract mucosal surfaces resulting in the establishment of infection.

\section{Materials and methods}

\section{Bacteria}

Single test strains of Haemophilus influenzae, Neisseria gonorrhoeae and Streptococcus pneumoniae were originally isolated from clinical specimens and had been maintained for several months on cooked blood agar. Fifteen strains of Proteus mirabilis (see table) were selected from a wide variety of clinical sources and places and were of diverse bacteriocine $(\mathrm{P} / \mathrm{S})$ and $\mathrm{O}$ antigenic types. The strains were identified according to standard methods (Senior and Leslie, 1986) and stored on nutrient-agar slopes at $4^{\circ} \mathrm{C}$. $\mathrm{P} / \mathrm{S}$ typing and $\mathrm{O}$ serotyping of strains were performed as previously described (Larsson and Olling, 1977; Senior, 1977; Senior and Larsson, 1983).

\section{Media}

Nutrient Agar (Oxoid CM 3) and blood agar (BA) composed of Columbia Agar Base (Oxoid CM 331) with sterile horse blood (Oxoid SR 50) $5 \%$ v/v were prepared and sterilised according to the manufacturer's instructions. Cooked blood agar (CBA) was heated BA. Modified New York City Medium (MNYC) was prepared according to the method of Young (1978) but with horse blood (Oxoid SR 50).

\section{Preparation of purified ${ }^{125}$ I-labelled IgA}

IgA was purified from frozen normal human plasma. After thawing, calcium chloride was added to a concentration of $20 \mathrm{~mm}$ and fibrin clots were removed by 
Table. Characteristics of the $P$. mirabilis strains examined

\begin{tabular}{|c|c|c|c|c|c|}
\hline \multicolumn{2}{|c|}{$\begin{array}{c}\text { Strain } \\
\text { no. }\end{array}$} & \multirow{2}{*}{$\frac{\mathrm{P} / \mathrm{S} \text { type }}{3 / 1,8,13}$} & \multirow{2}{*}{$\begin{array}{c}\text { Source and clinical symptoms } \\
\text { urine-chronic urinary tract infection }\end{array}$} & \multirow{2}{*}{ O type } & \multirow[t]{2}{*}{ Origin } \\
\hline 1 & 64676 & & & & \\
\hline 2 & 50213A & $3 / 1,8$ & urine-chronic urinary tract infection & O 3 & Dundee \\
\hline 3 & 50253 & $3 / 1,13$ & urine - chronic urinary tract infection & O 10 & Dundee \\
\hline 4 & SW 46 & $1 / 3$ & faeces-not known & O 24 & Gothenburg, Sweden \\
\hline 5 & F40010 & $0 / 7$ & faeces-diarrhoea & O 41 & Dundee \\
\hline 6 & F59242 & $1 / 0$ & faeces-diarrhoea & O 27 & Dundee \\
\hline 7 & $49704 / 80$ & $2 / 1$ & ureter-ureter stone & $\ldots$ & Dundee \\
\hline 8 & $75844 / 77$ & $5 / 0$ & kidney-renal stone & $\ldots$ & Dundee \\
\hline 9 & $33025 \mathrm{~N}$ & $3 / 10$ & cerebellum-abscess & $\ldots$ & London \\
\hline 10 & PR 22 & $4 / 11$ & ear-chronic suppurative otitis media & $\ldots$ & Glasgow \\
\hline 11 & OPF 10 & $3 / 4,10$ & faeces-control healthy person & $\ldots$ & Dundee \\
\hline 12 & EW 5 & $6 / 2,3$ & sputum - not known & $\ldots$ & Bristol \\
\hline 13 & U6450 & $3 / 1,13$ & urine-chronic urinary tract infection & $\ldots$ & Wurzburg, Germany \\
\hline 14 & $81662 / 85$ & $3 / 8,13$ & vagina-pelvic sepsis & $\ldots$ & Dundee \\
\hline 15 & PB 12 & $5 / 7$ & urine-chronic urinary tract infection & 06 & Portsmouth \\
\hline
\end{tabular}

filtration through glass wool. Ammonium sulphate was added to the resulting serum to $50 \%$ saturation. After standing overnight at $4^{\circ} \mathrm{C}$, the precipitate was collected by centrifugation, dissolved in distilled water, applied to a G 200 Sephadex column and eluted with $50 \mathrm{~mm}$ Tris$\mathrm{HCl} p \mathrm{H} \mathrm{8.0.} \mathrm{IgA} \mathrm{peak} \mathrm{fractions} \mathrm{were} \mathrm{collected} \mathrm{and}$ purified by ion-exchange chromatography on a FPLC Mono $Q$ column (Pharmacia) eluted with a linear gradient of $0-0.5 \mathrm{M} \mathrm{NaCl}$ in $50 \mathrm{~mm}$ Tris- $\mathrm{HCl}, p \mathrm{H} \mathrm{8.0.} \mathrm{Peak} \mathrm{IgA}$ fractions were further purified by gel filtration on a FPLC Superose-6 column (Pharmacia) with phosphate-buffered saline $p \mathrm{H} 7 \cdot 4$. The resultant pure $\operatorname{IgA}$ was labelled with ${ }^{125} \mathrm{I}$ by the chloramine-T method of Hunter and Greenwood (1962).

\section{Preparation of $\operatorname{IgA}$ protease}

Circular disks (approximately $8.5 \mathrm{~cm}$ diameter) cut from dialysis tubing were sterilised in water at $121^{\circ} \mathrm{C}$ for $15 \mathrm{~min}$ and placed flat on to the surface of plates of culture media (BA for $P$. mirabilis strains, CBA for $H$. influenzae and $S$. pneumoniae, and MNYC for $N$. gonorrhoeae) by the use of a sterile cotton-wool swab. The surface of the membrane was inoculated with a cottonwool swab containing one of the bacterial strains and the plates were incubated overnight at $37^{\circ} \mathrm{C}$ in the presence of $\mathrm{CO}_{2} 8 \%$. Bacteria were than scraped from the membrane with a microscope slide and transferred to a microcentrifuge tube. The membrane was rinsed with $0.5 \mathrm{ml}$ of $5 \mathrm{~mm}$ Tris- $\mathrm{HCl}$ buffer $p \mathrm{H} 7.2$ which was also added to the tube. The cells were emulsified in the buffer, centrifuged for $2 \mathrm{~min}$ at $11600 \mathrm{~g}$ and the clear supernate containing IgA protease removed.

\section{Digestion of ${ }^{125}$ I IgA with $\operatorname{Ig} A$ protease}

${ }^{125} \mathrm{I}$ IgA $(25 \mu \mathrm{g} / \mathrm{ml}$ of phosphate-buffered saline, $p \mathrm{H} \mathrm{7.4)} \mathrm{was} \mathrm{incubated} \mathrm{in} 2.5-\mu \mathrm{l}$ amounts with $50 \mu \mathrm{l}$ of
IgA protease preparations in $5 \mathrm{~mm}$ Tris- $\mathrm{HCl}$ buffer, $p \mathrm{H} \mathrm{7.2,} \mathrm{for} 20 \mathrm{~h}$ at $37^{\circ} \mathrm{C}$. EDTA at a final concentration of $5 \mathrm{~mm}$ or phosphoramidon (Sigma, Dorset, England) at a final concentration of $2 \mu \mathrm{M}$ was added to some reactions. After incubation, $25 \mu \mathrm{l}$ of buffer $(0.1 \mathrm{M}$ Tris- $\mathrm{HCl}, p \mathrm{H} 8.0$, containing $80 \mathrm{~mm}$ dithiothreitol, $8 \mathrm{M}$ urea, SDS $2 \% \mathrm{w} / \mathrm{v}$ and a trace of bromophenol blue dye) was added to each sample. After standing in boiling water for $2 \mathrm{~min}$ the samples were subjected to electrophoresis.

\section{Polyacrylamide gel electrophoresis and autoradiography}

Test samples and standard protein mol.-wt markers were analysed by SDS discontinuous polyacrylamide gel electrophoresis (PAGE) by the method of Laemmli (1970). The resolving gel was a linear gradient of 5-22.5\% $\mathrm{w} / \mathrm{v}$ acrylamide and electrophoresis was performed at $40 \mathrm{~mA}$ until the dye front reached the bottom of the gel. Gels were stained in Coomassie Brilliant Blue R250 $0.125 \% \mathrm{w} / \mathrm{v}$ in methanol $50 \% \mathrm{v} / \mathrm{v}$ and glacial acetic acid $20 \% \mathrm{v} / \mathrm{v}$ in water for $1-2 \mathrm{~h}$. They were subsequently destained in methanol $30 \% \mathrm{v} / \mathrm{v}$ and glacial acetic acid $10 \% \mathrm{v} / \mathrm{v}$ in water, dried under vacuum, and exposed to $X$ Omat AR film at $-70^{\circ} \mathrm{C}$. After an appropriate period the film was developed.

\section{Results}

The PAGE analyses of the products of ${ }^{125}$ I IgA digestion with enzymes produced by $P$. mirabilis strain 64676--a strain associated with chronic urinary tract infections - and those of $N$. gonorrhoeae, $H$. influenzae and $S$. pneumoniae are shown in fig. 1 . The $P$. mirabilis enzyme cleaved the IgA heavy chain at positions different from the hinge region cleavage sites of the other bacterial IgA 


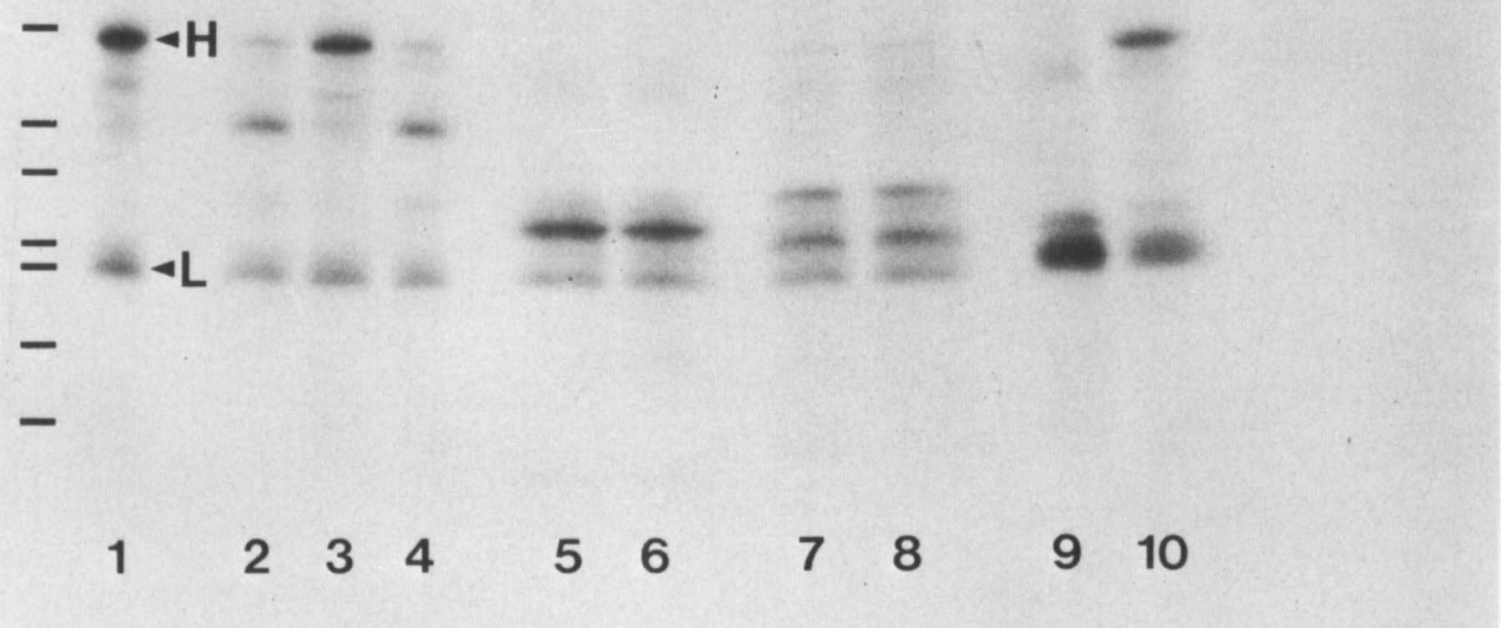

Fig. 1. Polyacrylamide gel analysis of ${ }^{125} \mathrm{I} \mathrm{IgA}$ digested with various microbial IgA proteases. The $P$. mirabilis protease is EDTA sensitive and cleaves the IgA heavy chain at sites different from those attacked by other bacterial proteases. Left; position of mol. wt standards from top to bottom; bovine albumin (66 000), ovalbumin (45000), glyceraldehyde-3-phosphate dehydrogenase (36 000), carbonic anhydrase (29 000), trypsinogen (24 000), trypsin inhibitor $(20100)$, $\alpha$ lactalbumin $(14200)$. Tracks contain ${ }^{125} I$ IgA cleaved with enzymes as follows: 1 . control untreated IgA-H $=$ heavy chain, $\mathrm{L}=$ light chain; 2. P. mirabilis strain 64676 protease; 3. P. mirabilis strain 64676 protease with $5 \mathrm{mM}$ EDTA; 4. P. mirabilis strain 64676 protease with $2 \mu \mathrm{M}$ phosphoramidon; 5 . N. gonorrhoeae protease; $6 . N$. gonorrhoeae protease with $5 \mathrm{mM}$ EDTA; 7 . H. influenzae protease; 8 . H. influenzae protease with 5 mM EDTA; 9. S. pneumoniae protease; 10. S. pneumoniae protease with 5 mM EDTA.

proteases. The mol. wts of the $P$. mirabilis-cleaved fragments were approximately 47000 and 34000 . The $P$. mirabilis enzyme was inhibited by $5 \mathrm{~mm}$ EDTA but not by phosphoramidon, an inhibitor of several metalloproteinases (Umezawa and Aoyagi, 1977). The IgA protease of $S$. pneumoniae was also EDTA sensitive but the IgA proteases of $N$. gonorrhoeae and $H$. influenzae were not inhibited by 5 mM EDTA.

The kinetics of $\operatorname{IgA}$ degradation by the enzymes from $P$. mirabilis strain 64676 are shown in fig. 2. The IgA heavy chain (mol. wt 68000 ) appeared to be cleaved to a fragment of mol. wt 47000 in a single step, because larger fragments of intermediate size were not seen before the formation of the $47000-\mathrm{mol}$. wt fragment. The kinetics of formation of the fragment of $34000 \mathrm{~mol}$. wt appeared to be synchronous with that of the fragment of mol. wt 47000 . This suggested that the smaller fragment did not arise by secondary proteolysis of the larger fragment. Cleavage products of the $\operatorname{IgA}$ heavy chain smaller than mol. wt 34000 were not observed.

Fifteen strains of $P$. mirabilis (see table), with 14 distinct $\mathrm{P} / \mathrm{S}$ types and at least seven different $\mathrm{O}$ antigens, isolated from patients with various clinical symptoms and from healthy carriers in several geographical locations, all produced an $\operatorname{IgA}$ protease (fig. 3). The products of IgA cleavage by the enzyme from each strain were of the same size as those generated by the $\operatorname{IgA}$ protease from $P$. mirabilis strain 64676.

\section{Discussion}

IgA1 proteases are a group of enzymes that specifically cleave the heavy chain of the $\operatorname{IgA} 1$ subclass of human immunoglobulin $\mathrm{A}(\operatorname{IgA})$ at sites 


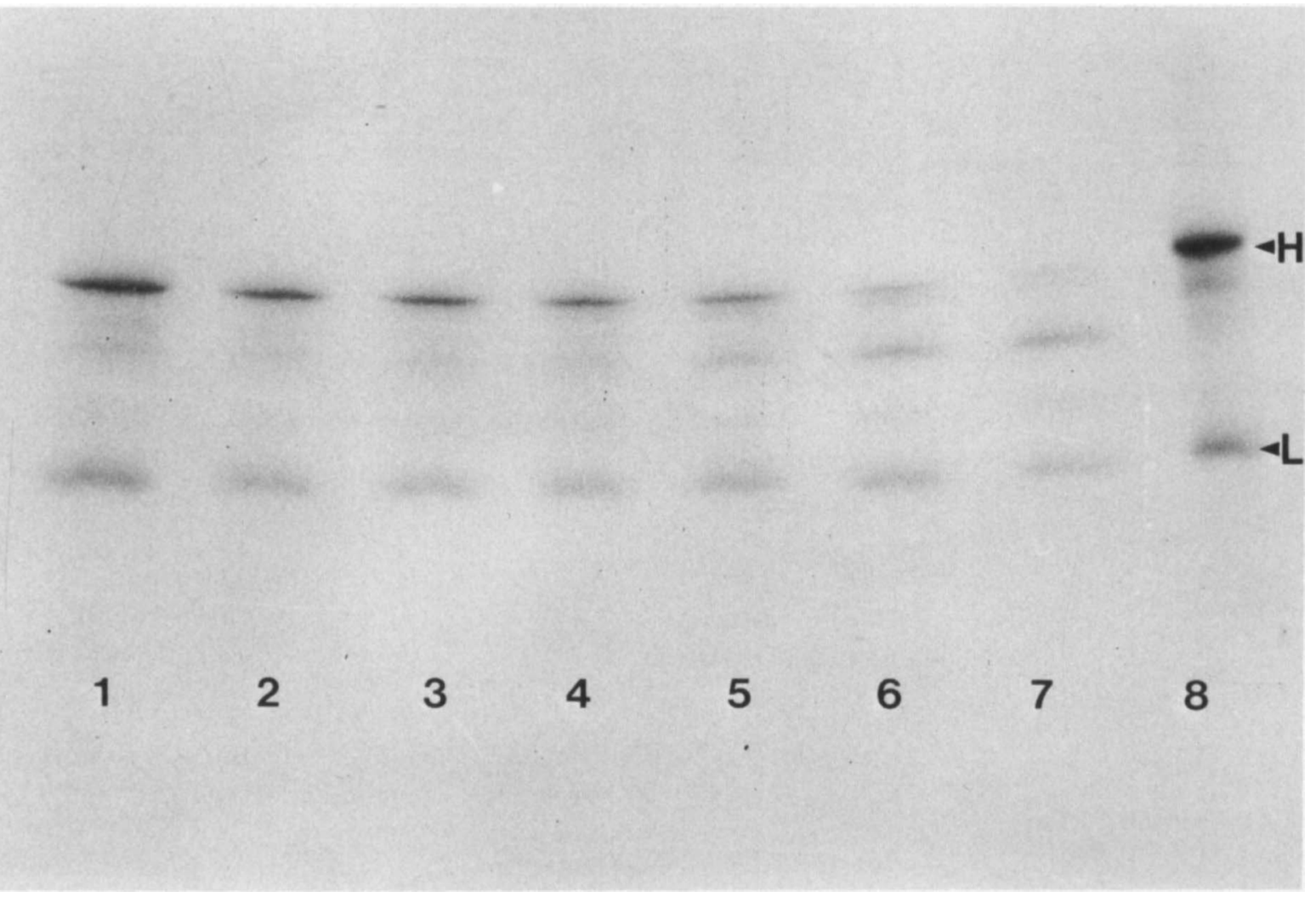

Fig. 2. Polyacrylamide gel analysis of $\mathrm{IgA}$ degradation kinetics by $P$. mirabilis strain 64676 protease showing the simultaneous appearance of fragments of mol. wt 47000 and 34000 . Lanes 1-7: ${ }^{125} \mathrm{I}$ IgA incubated with protease at $37^{\circ} \mathrm{C}$. EDTA was added to samples of the mixture after (left to right) $0,0 \cdot 5,1,2,4,12$ and $20 \mathrm{~h}$ to a final concentration of $5 \mathrm{~mm}$ to terminate the reaction; incubation was continued for a total of $20 \mathrm{~h}$. Lane $8:{ }^{125} \mathrm{I} \mathrm{IgA} \mathrm{was} \mathrm{incubated} \mathrm{without} \mathrm{protease} \mathrm{for} 20 \mathrm{~h}$ at $37^{\circ} \mathrm{C}(\mathrm{Control})-\mathrm{H}=\mathrm{heavy}$ chain; $\mathbf{L}=$ light chain.

within a 16-amino-acid proline-rich polypeptide in the hinge region. This polypeptide sequence is absent from $\operatorname{IgA} 2$ which, as a consequence, is resistant to the protease. IgAl proteases are stably produced in vitro and in vivo (Sorensen and Kilian, 1984) by several human pathogens (Kilian et al., 1983a), including S. pneumoniae (Kilian et al., 1979; Male, 1979; Mulks et al., 1980a), N. gonorrhoeae (Plaut et al., 1975; Blake and Swanson, 1978), $N$. meningitidis (Plaut et al., 1975; Mulks et al., 1980b) and $H$. influenzae (Kilian et al., 1979 and 1983b; Male, 1979; Mulks et al., 1980a). Non-pathogenic members of the same genera do not produce IgA proteases (Mulks and Plaut, 1978; Kilian et al., 1979; Male 1979) which suggests that this enzyme may be involved in virulence.

While investigating virulence mechanisms of $\boldsymbol{P}$. mirabilis for the urinary tract, we found that the uropathogenic strain 64676 produced an enzyme able to cleave the IgA heavy chain to a fragment of mol. wt 47000 . Removal of carbohydrate from the heavy chain by glycosidase activity would not result in such a reduction in mol. wt, whereas deglycosylation of the several carbohydrate chains would result in the formation of cleaved products intermediate in size between intact heavy chain and the observed final cleavage product. Such intermediates were not observed, which suggests that the enzyme was a protease rather than a glycosidase. There are also several possible explanations for the formation of two fragments from the heavy chain, but further studies are required before any other conclusions are made on the nature of this enzyme.

Since the size of the fragments cleaved by the enzymes from the other 14 strains of $P$. mirabilis of diverse type were indistinguishable from those cleaved by the $P$. mirabilis strain $64676 \operatorname{IgA}$ protease, it appears that most strains of $P$. mirabilis produce a similar type of IgA protease. IgA protease production by $\boldsymbol{P}$. mirabilis may, therefore, be an important virulence factor, not only in urinary tract infections but in infections at other sites. 


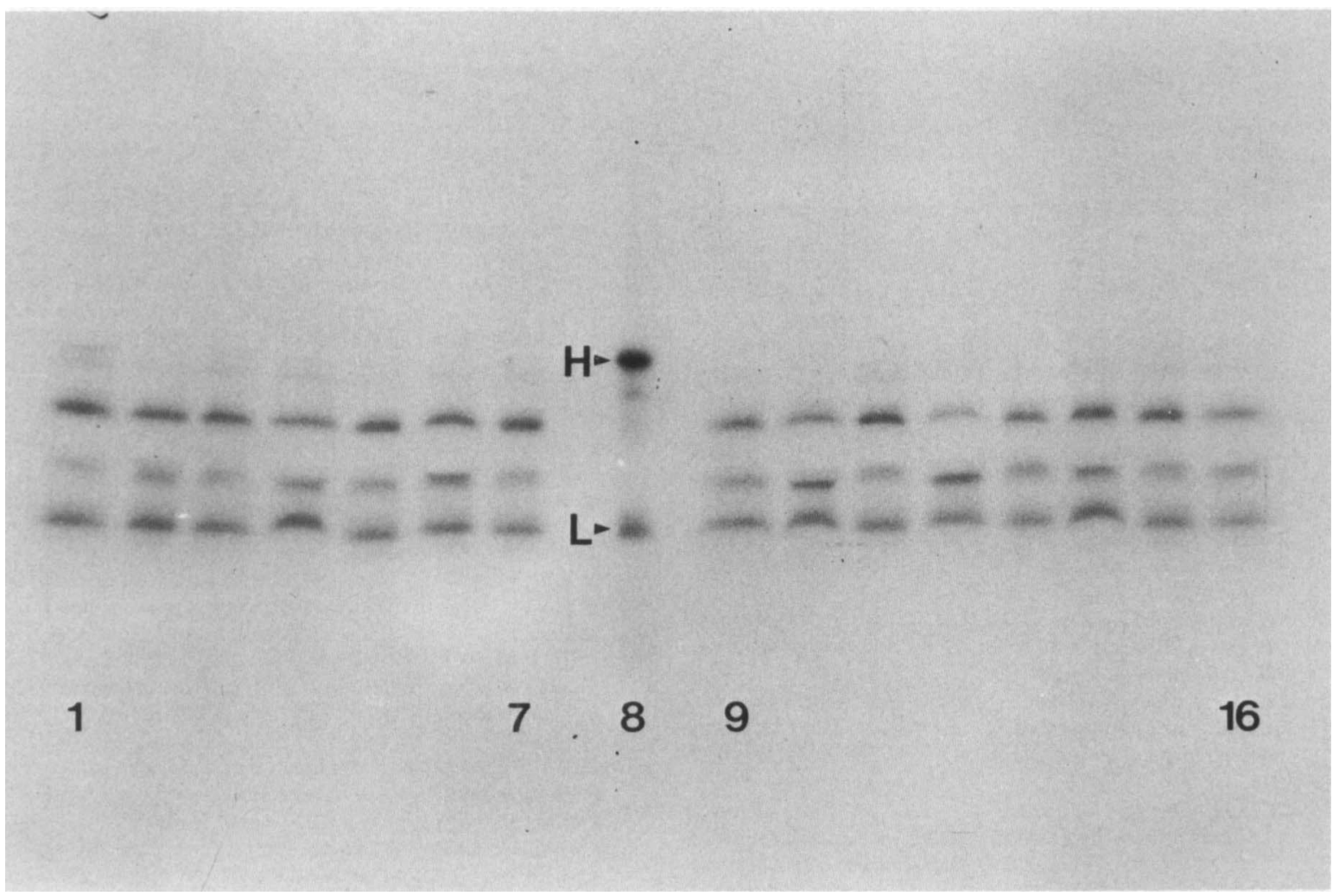

Fig. 3. Polyacrylamide gel analysis of ${ }^{125} \mathrm{I}$ IgA digested with proteases from different $P$. mirabilis strains. The cleaved IgA fragments were similar in size to those resulting from cleavage with $P$. mirabilis strain 64676 protease. From the left are enzymic digests of IgA from strains in the same order as in the table. Control undigested IgA was in lane $8-\mathbf{H}=$ heavy chain, $\mathrm{L}=$ light chain.

We confirmed previous findings (Kilian et al., $1983 a$ ) that the IgA1 proteases of $N$. gonorrhoeae and $H$. influenzae are relatively resistant to EDTA whereas that of $S$. pneumoniae is EDTA sensitive. The $P$. mirabilis IgA protease was metal chelatorsensitive but differed from other $\operatorname{IgA} 1$ proteases by cleaving $\operatorname{IgA}$ outside the hinge region. It may,

\section{REFERENCES}

Adegbola R A, Old D C, Senior B W 1983 The adhesins and fimbriae of Proteus mirabilis strains associated with high and low affinity for the urinary tract. Journal of Medical Microbiology 16:427-431.

Bergstrom T 1972 Sex differences in childhood urinary tract infection. Archives of Diseases of Childhood 47:227-232.

Blake M S, Swanson J 1978 Studies on gonococcus infection. XVI. Purification of Neisseria gonorrhoeae immunoglobulin Al protease. Infection and Immunity 22 : 350-358.

Braude A I, Siemienski J 1960 Role of bacterial urease in experimental pyelonephritis. Journal of Bacteriology 80: $171-179$.

Braude A I, Siemienski J, Shapiro A B 1960 The role of bacterial urease in the pathogenesis of pyelonephritis. In: Quinn E therefore, also have activity on $\operatorname{IgA} 2$ which would be advantageous to a pathogen.

We are grateful to Drs P. Hawkey, C. Hughes, P. Larsson, R. Maskell, P. Noone and G. Sweeney for the gift of some of the strains. One of us (M.A.) acknowledges financial support from the EEC Interdisciplinary Training Grant and from NATO (NATO Science Fellowship) and from the Danish Science Research Council.

L, Kass E H (eds) Biology of pyelonephritis. Churchill Livingstone, London, pp 69-88.

Fairley K F et al. 1971 Site of infection in acute urinary tract infection in general practice. Lancet 2:615-618.

Griffith D P, Musher D M, Campbell J W 1973 Inhibition of bacterial urease. Investigative Urology 11:234-238.

Hallett R J, Pead L, Maskell R 1976 Urinary infection in boys. A three year prospective study. Lancet 2:1107-1110.

Hunter W M, Greenwood F C 1962 Preparation of iodine-131 labelled human growth hormone of high specific activity. Nature 194:495-496.

Khan A J, Ubriani R S, Bombach E, Agbayani M M, Ratner H, Evans H E 1978 Initial urinary tract infection caused by Proteus mirabilis in infancy and childhood. Journal of Pediatrics 93:791-793.

Kilian M, Mestecky J, Schrohenloher R E 1979 Pathogenic 
species of the genus Haemophilus and Streptococcus pneumoniae produce immunoglobulin $\mathrm{Al}$ protease. Infection and Immunity 26: 143-149.

Kilian M, Thomsen B, Petersen T E, Bleeg H S $1983 a$ Occurrence and nature of bacterial IgA proteases. Annals of the New York Academy of Sciences 409:612-624.

Kilian M, Thomsen B, Petersen T E, Bleeg H $1983 b$ Molecular biology of Haemophilus influenzae IgA1 proteases. Molecular Immunology 20: 1051-1058.

Laemmli U K 1970 Cleavage of structural proteins during the assembly of the head of bacteriophage T4. Nature 227:680685.

Larsson P, Olling S 1977 O antigen distribution and sensitivity to the bactericidal effect of normal human serum of Proteus strains from clinical specimens. Medical Microbiology and Immunology 163:77-82.

MacLaren D M 1968 The significance of urease in Proteus pyelonephritis: a bacteriological study. Journal of Pathology and Bacteriology 96:45-56.

MacLaren D M 1969 The significance of urease in Proteus pyelonephritis: a histological and biochemical study. Journal of Pathology 97:43-49.

Male C J 1979 Immunoglobulin A1 protease production by Haemophilus influenzae and Streptococcus pneumoniae. Infection and Immunity 26: 254-261.

Mulks M H, Plaut A G $1978 \mathrm{IgA}$ protease production as a characteristic distinguishing pathogenic from harmless Neisseriaceae. New England Journal of Medicine 299:973976.

Mulks M H, Kornfeld S J, Plaut A G 1980a Specific proteolysis of human IgA by Streptococcus pneumoniae and Haemophilus influenzae. Journal of Infectious Diseases 141 :450-456.

Mulks M H, Plaut A G, Feldman H A, Frangione B 1980b IgA proteases of two distinct specificities are released by Neisseria meningitidis. Journal of Experimental Medicine 152: 1442-1447.

Musher D M, Griffith D P, Yawn D, Rossen R D 1975 Role of urease in pyelonephritis resulting from urinary tract infection with Proteus. Journal of Infectious Diseases $131: 177-181$.

Pazin G J, Braude A I 1974 Immobilizing antibodies in urine. II. Prevention of ascending spread of Proteus mirabilis. Investigative Urology 12:129-133.

Peerbooms P G H, Verweij A M J J, MacLaren D M 1983 Investigation of the haemolytic activity of Proteus mirabilis strains. Antonie van Leeuwenhoek 49: 1-11.

Peerbooms P G H, Verweij A M J J, MacLaren D M 1984 Vero cell invasiveness of Proteus mirabilis. Infection and Immunity 43: $1068-1071$.
Plaut A G, Gilbert J V, Artenstein M S, Capra J D 1975 Neisseria gonorrhoeae and Neisseria meningitidis: extracellular enzyme cleaves human immunoglobulin A. Science 190: 1103-1105.

Senior B W 1977 Typing of Proteus strains by proticine production and sensitivity. Journal of Medical Microbiology 10:7-17.

Senior B W 1979 The special affinity of particular types of Proteus mirabilis for the urinary tract. Journal of Medical Microbiology 12:1-8.

Senior B W 1983a Proteus morgani is less frequently associated with urinary tract infections than Proteus mirabilis--an explanation. Journal of Medical Microbiology 16:317-322.

Senior B W $1983 b$ The purification, structure and synthesis of proticine 3. Journal of Medical Microbiology 16:323-331.

Senior B W, Bradford N C, Simpson D S 1980 The ureases of Proteus strains in relation to virulence for the urinary tract. Journal of Medical Microbiology 13:507-512.

Senior B W, Larsson P 1983 A highly discriminatory multityping scheme for Proteus mirabilis and Proteus vulgaris. Journal of Medical Microbiology 16:193-202.

Senior B W, Leslie D L 1986 Rare occurrence of Proteus vulgaris in faeces: a reason for its rare association with urinary tract infections. Journal of Medical Microbiology 21 : 139-144.

Silverblatt F J 1974 Host-parasite interaction in the rat renal pelvis. A possible role for pili in the pathogenesis of pyelonephritis. Journal of Experimental Medicine 140 : 16961711.

Silverblatt F J, Ofek I 1978 Influence of pili on the virulence of Proteus mirabilis in experimental hematogenous pyelonephritis. Journal of Infectious Diseases 138:664-667.

Sorensen C H, Kilian M 1984 Bacterium-induced cleavage of IgA in nasopharyngeal secretions from atopic children. Acta Pathologica, Microbiologica et Immunologica Scandinavica Section C 92:85-87.

Svandborg Edén C, Larsson P, Lomberg H 1980 Attachment of Proteus mirabilis to human urinary sediment epithelial cells in vitro is different from that of Escherichia coli. Infection and Immunity 27:804-807.

Umezawa H, Aoyagi T 1977 Activities of proteinase inhibitors of microbial origin. In: Barrett A J (ed) Proteinases in mammalian cells and tissues. North Holland, Amsterdam, pp 637-662.

Walkey F A, Judge T G, Thompson J, Sarkari N B 1967 Incidence of urinary infection in the elderly. Scottish Medical Journal 12:411-414.

Young H 1978 Identification and penicillinase testing of Neisseria gonorrhoeae from primary isolation cultures on modified New York City medium. Journal of Clinical Microbiology 7:247-250. 